\title{
RELIGION OG MANGFOLDIGHEDEN AF IDENTITETER
}

En undersøgelse af forholdet mellem religion og nationalisme

\author{
Martin Sökefeld
}

\section{Indledning}

Hvem er du? Hvem er jeg? Disse tilsyneladende uskyldige spørgsmål giver anledning til en vrimmel af komplicerede teoretiske spørgsmål. De er grundlæggende for både filosofisk selvrefleksion og voldelige konflikter og henviser til noget, der er blevet et nøglebegreb inden for den nutidige diskurs, nemlig identitet. På et helt banalt niveau forbindes en persons identitet med hans eller hendes identitetskort. Identitetskort er faktisk et bekvemt udgangspunkt, når man vil reflektere over emner, der vedrører identitet. Et identitetskort indeholder oplysninger om navn, fødselsdato, fødested og øjenfarve, der tjener til at identificere en person som et unikt menneske, der ikke kan forveksles med andre. Der er imidlertid også andre identitetsoplysninger, hvoraf de vigtigste er nationalitet og køn; dertil kommer religion som fx i Tyrkiet og Pakistan, der i modsætning til de nævnte personlige data, siger noget om, hvad det enkelte menneske har til fælles med andre i kraft af et formodet tilhørsforhold til en bestemt nation, til køn eller til et religiøst fællesskab. Denne dobbelthed ved identitet er meget præcist udtrykt i følgende citat af Erik Erikson: “the term 'identity' expresses such a mutual relation in that it connotes both a persistent sameness within oneself (selfsameness) and a persistent sharing of some kind of essential characteristics with others" (Erikson 1980, 109). I denne artikel vil jeg især beskæftige mig med det sidstnævnte aspekt: identitet som det, der skaber et fællesskab med andre, selvom jeg er af den opfattelse, at de to aspekter faktisk ikke kan adskilles.

Inden for min disciplin, socialantropologien, har identitetsdiskussionen især været fokuseret på 'etnisk identitet', men jeg tror - uanset problemet med at definere, hvad der er 'etnisk' (se Sökefeld 1997a) - at en tilgang, der fremhæver én ud af en kompleks række af mulige identifikationer, er alt for snæver og muligvis vildledende. I stedet foreslår jeg en konceptualisering af identitet, der er inspireret af andre discipliner såsom kulturstudier og akademisk feminisme, der fra første færd har betragtet identitet som indskrevet i et rum kendetegnet ved et indbyrdes samspil imellem dets enkelte komponenter. Jeg ser tre grundaspekter ved identitet, som kan udtrykkes med ordene forskel, mangfoldighed og intersektionalitet.

Forskel ophæver nærmest Eriksons definition af identitet som ensartethed. Forskel understreger netop, at identitet kun eksisterer som en forskelssætten, idet man skelner en person fra en anden eller en gruppe eller kategori fra en anden ved at fremhæve modsætningerne. Når nationalitet er indført i vore pas, er det ikke fordi, alle inden for samme nationalitet anses for at være ens, men fordi forskellen i folks nationalitet er afgørende. Forskel peger på den kendsgerning, at identitet skabes i kontrast til andre. Mens 
der i forståelsen af identitet som ensartethed lægges vægt på, at man er identisk med andre eller med sig selv, fremhæver identitet som forskel modsætningen som en nødvendig identitetsforudsætning.

Mangfoldighed betyder, at identitet ikke findes i ental, men kun som identiteter dannet gennem en pluralitet af det at høre til og det at udgøre 'det andet'. Det er vigtigt at forstå, at identiteter i denne kontekst, som det foregående eksempel viser, ikke kun eksisterer i en mangfoldighed, fordi der er mange forskellige nationaliteter, men fordi der er mange andre forskelle, der adskiller og forener mennesker på tværs af disse. Dvs., at der foruden national identitet er kønsidentitet, religiøs identitet osv., og som i hvert enkelt tilfælde adskiller mig fra og forener mig med en bestemt gruppe af andre mennesker.

Intersektionalitet implicerer, at der er specifikke dynamiske former for samspil mellem disse forskellige former for forskelle, som bør undersøges. De forskellige identiteter, som en person er bærer af, kan påvirke hverandre voldsomt, ikke nødvendigvis i den betydning, at de alle på en eller anden måde er gensidigt tilpasset for at muliggøre en konsistent personlighed eller 'overordnet identitet', men snarere i den betydning, at de kan føre til konflikt og antagonisme, dvs. de avler inkonsistens og ambivalens. Det er især intersektionalitet, der tvinger os til at analysere identitet som et krydsfelt mellem flere forskellige relationer og ikke som en enkelt kategori.

Inden for samfundsvidenskaberne har debatten om identitet i årtier været en udveksling af primordialistiske og konstruktionistiske synsvinkler. Jeg vil hævde, at denne debat stort set er faldet ud til konstruktionisternes fordel. Men vi må nu affinde os med det fænomen, at flere og flere mennesker (og folkeslag) insisterer på at 'have' en identitet, som er formet på præcis dén primordialistiske måde, der i den akademiske diskurs er blevet forkastet. Edwin Wilmsen taler med henvisning til etnicitet således om en primordialistisk intertekstualitet i identitetsdebatten: "Indeed, primordialism cannot help but be a subtext - for ethnicity as an existential presence is founded on just one premise: the conviction of the reality of endemic cultural and social, often racial, difference" (1996, 2).

På det analytiske niveau refererer denne "subtext of primordialism” til den måde, hvorpå identitet er konstrueret, da henvisningen til primordialisme, til historiske rødder og evige sandheder er et vigtigt middel til at skabe identiteter, til at overbevise individer om, at de virkelig er, hvad de forudsættes at være. Her går vi ind på området identitetspolitik, som nødvendigvis er forbundet med en specifik repræsentationspolitik. En sådan identitetspolitik har til hensigt at udelukke ambivalens og tvivl om en bestemt identitet. Identitet essentialiseres som tidløs og rodfæstet, som 'naturlig' og altomfavnende. De andre er ganske enkelt anderledes. Historiske analyser viser i de fleste tilfælde helt tydeligt, hvordan konkrete, reificerede, 'evige’ identiteter er blevet skabt. Men den teoretiske forsikring om, at primordialistiske repræsentationer 'beviser' identitetens konstruerethed, lader stadigvæk et meget vigtigt spørgsmål stå åbent, som jeg vil se nærmere på senere. Først vil jeg diskutere religionens stilling inden for disse rammer. 


\section{Religion og mangfoldigheden af identiteter}

Inden for konceptualiseringen af identitet som forskel, mangfoldighed og intersektionalitet, kan religion ganske enkelt betragtes som en bestemt slags forskel. Da jeg arbejdede med identiteter i det nordlige Pakistan, identificerede jeg således adskillige 'former for forskel' såsom lokalt tilhørsforhold, sprog og afstamning, og jeg anså religion for blot at være en af disse (Sökefeld, 1997b).

I dag forskes der i rigt mål i religion set inden for rammerne af identitet. Skønt, som Martin E. Marty $(1997,2)$ skriver, at "religion, most of the time for most people, is not an instrument for killing”, ser det ud til, at der nu til dags især skabes opmærksomhed om religion, når den fremstilles som stående i forbindelse med voldelige konflikter. Det er i dag almindeligt at betragte religion som kilden til konflikter, til vold og uforsonlighed. Vi er fx blevet vænnet til at se konflikterne på Balkan fremstillet i pressen som anliggender mellem religiøst definerede grupper, i dette tilfælde muslimer og kristne, ortodokse og katolikker. Religion fremstilles som grobund for 'fanatisme' og 'fundamentalisme'. Det er vigtigt at forstå, at dette billede af religion som 'fanatisme' som det, der dominerer sociale og politiske forhold, er skabt ved at dekontekstualisere religion, ved at trække den ud af en række komplekse og flerstrengede relationer og ofte ved at knytte den til andre former for identiteter.

Hvis vi betragter religion som en slags forskel, er der ikke nødvendigvis nogen forbindelse mellem religiøs identitet og andre forskelle. Det kan være, at religion og en anden identitet gensidigt forstærker hinanden i en sådan grad, at de faktisk bliver uadskillelige. Fx kan religion og national identitet $i$ kombination danne en slags religiøs nationalisme. Men religion og en anden identitet som fx nationalitet kan også destabilisere og udviske hinanden. Endelig kan forbindelsen mellem religiøs identitet og andre identiteter være så svag, at de synes uden nogen forbindelse. Dette synes i nogen grad tilfældet i Tyskland, hvor religion i det mindste blandt kristne i overvejende grad anses for et privat anliggende, og som derfor ikke tilskrives betydning for andre af livets områder.

For at indskrænke denne artikels omfang og for at kunne forholde mig til noget helt konkret, vil jeg i det følgende fokusere på forbindelsen mellem religion og nationalisme. Fordi religiøse identiteter ikke er faste skabeloner, men personlige perspektiver, kan forskellige og selvmodstridende visioner og praksisformer i forbindelse med religiøs identitet og nationalitet eksistere side om side i et bestemt samfund. Det er vigtigt at huske på, at særlige former for relationer mellem religion og andre identiteter altid er historisk betingede. De er ikke et resultat af 'religion i sig selv' eller en anden form for identitet i sig selv. I stedet er de påvirket af komplekse historiske konstellationer og kontekster, og de er naturligvis underkastet forandring, hvis disse kontekster ændrer sig. I nærværende artikel vil jeg hovedsagelig diskutere to eksempler, i hvilke intersektionalitet mellem religiøs og national identitet spiller væsentlige, men forskellige roller. Hindunationalisme i Indien vil blive diskuteret som et eksempel på, hvordan religiøs identitet er blevet tæt forbundet med national identitet. Det andet eksempel, der stammer fra 
det nordlige Pakistan, vil vise, hvordan national identitet også kan bruges som strategi til at modvirke religiøs forskel.

\section{Religion og nationalisme}

Oprindelig opstod nationalisme i Europa i det 18. århundrede som en ideologi med folket i fokus, og den satte sig op imod såvel adelens som gejstlighedens privilegier. Nationalisme ansås derfor ofte for at være antireligiøs. Tidligere havde politisk magt været religiøst legitimeret, men nu fremsatte nationalismen en sekulær ideologi, der krævede magt til dem, der tidligere havde være udelukket fra den politiske verden. Der blev dog hurtigt knyttet tætte bånd mellem religion og nationalisme, så snart tanken om kulturelt forskellige nationer, som havde rødder i romantikken, var blevet etableret, og så snart nationalismen var blevet den dominerende teori til at understøtte politiske tiltag. Frem for at forblive en revolutionær kraft blev den nationalistiske ideologi et instrument i de etablerede magters hænder, således at det kun få år efter den franske revolution blev et nationalt imperativ ikke at afsætte kongen, men at kæmpe og dø for ham (jf. Schulze 1999). Ligesom det politiske system med kongen og adelen øverst tidligere havde været religiøst legitimeret, blev opdelingen af menneskeheden i adskilte nationer nu også et spørgsmål om kristen, sund fornuft.

\section{Religiøs nationalisme}

Religiøs nationalisme, oprindelig en selvmodsigende sammenstilling, er i dag blevet en helt almindelig form for politisk ideologi. Tætte bånd mellem et bestemt religiøst tilhørsforhold og en nationalitet er måske en reminiscens fra den tid, da undersåtternes religiøse tilhørsforhold var bestemt af herskerens. Men i de fleste tilfælde bliver religion et centralt nationalistisk spørgsmål, når befolkningen i en bestemt politisk sammenhæng ikke deler religiøst tilhørsforhold.

I Religion and the Politics of Identity in Kosovo identificerer Ger Duijzings to mulige måder, hvorpå religion påvirker nationalistiske ideologier. Den første er den, hvor det religiøse tilhørsforhold anvendes til at afgrænse en nation. Det er fx tilfældet i Bosnien-Hercegovina, hvor det religiøse tilhørsforhold anses for et tilstrækkeligt kriterium for national (eller, som Duijzings skriver her, 'etnisk') identitet:

It is enough to know the confessional background of an individual to determine his or her ethnic identity. Ethnic identities are primarily expressed in religious customs, symbols and emblems, for instance in the way a person crosses oneself (using two or three fingers) or, as in the case of Muslim men, bodily marks like circumcision (2000, 30f).

Den anden måde, hvorpå religion fungerer i en nationalistisk kontekst, er mere generel og almindeligt udbredt. Det er anvendelsen af en religiøs sprogbrug og af religiøse symboler til nationalistisk mobilisering. Den form for nationalistisk brug af religionen findes også, hvor en bestemt nationalistisk ideologi ikke er baseret på et bestemt religiøst 
fællesskab. Det bruges især, hvor en nationalistisk ideologi forsøger at opildne til voldelige konflikter.

... Religious ceremonies and symbols induce feelings of belonging, and provide the means to sacralize the nation and demonise its enemies, to reduce complex social and historical realities to a clear and simple distinction between the forces of good and evil ... [T] he nation is often seen as a 'sacred community' for which individual members of the nation should be ready to die. Death, sacrifice, and martyrdom are usually important nationalist values which make nationalist ideology more often than not quite violent in character (32).

Men i sin analyse af mislykkede forsøg på at integrere symboler og myter fra Bektashiordenen i albanernes nationalistiske diskurs i det 19. århundrede, viser Duijzings også, at religion ikke nødvendigvis står til rådighed for en nationalistisk ideologis formål (157ff).

Et historisk meget veldokumenteret eksempel på religiøs nationalisme er hindunationalismen i Indien. Jeg vil opholde mig lidt ved dette, fordi det er et illustrativt eksempel på, hvordan identitetskategorier bliver en integreret del af den politisk diskurs og praksis.

Det er nu velkendt, at religiøse forskelligheder i Indien ikke fra 'tidernes morgen' har været støttet rent politisk, men at religiøst tilhørsforhold blev politisk afgørende i bestemte situationer under kolonistyret. Før det 19. århundrede var ordet 'hindu' ikke engang en betegnelse for et bestemt religiøst fællesskab, men simpelthen for alle indbyggerne på subkontinentet inklusive indiske kristne, jøder og sandsynligvis også mange af de muslimske samfund (Pandey 1993, 93). Siden slutningen af det 18. århundrede var briterne involveret i grundlæggelsen af et overordnet administrativt og juridisk system i Indien, som især inden for familieretten forsøgte at anerkende alle de formodede religionssamfunds særinteresser. For briterne var religiøs forskel et strukturelt element $\mathrm{i}$ det indiske samfund. Pandey (1996) skriver detaljeret om, hvordan Indiens historie hovedsagelig blev udformet som den store fortælling om konflikten mellem hinduer og muslimer (jf. også Freitag 1989). Gennem afbildningen som oprørske og voldelige blev både hinduer og muslimer forbundet med 'det andet' og gjort til den britiske civilisations modsætning - 'det andet', som en civiliserende mission skulle rette sig imod. Som svar på denne nedvurdering af de indiske traditioner forsøgte reformbevægelser at rekonstituere hinduisme som en entydig religion, skabt efter kristne og muslimske modeller, hvilket indbefattede begreber som nation og modernitet i en 'nativized' form, som Nandy m.fl. kalder det $(1997,57)$. De britiske forsøg på at specificere og kategorisere det indiske samfund nåede sit højdepunkt ved folketællingerne i Indien i 1872 og fortsatte derefter. "The odd effect of the census was that it simultaneously cut the society up into infinitesimal units and yet created a huge 'Hindu majority', together with several 'minorities', of which the most significant was the Muslim”, skriver van der Veer $(1994,26)$. 
Repræsentationspolitikken i dens dobbelte betydning påvirkede i høj grad forholdet mellem hinduer og muslimer. For det første forsøgte ledere af de respektive samfund at rekonstruere repræsentationerne på en sådan måde, at de både gjorde valgkredsene større og samtidig klart afmærkede deres grænser. Fx forsøgte Gandhi at redefinere de såkaldte 'urørlige', som stod uden for den skriftfunderede hinduisme som 'Harijans' (Guds eller rettere Vishnus børn). ${ }^{1}$ For det andet var de religiøse samfund repræsenteret i kolonistyrets institutioner for politisk medbestemmelse på basis af folketællingernes numeriske resultater. Ved indførelsen af separate valgkredse opnåede de religiøse samfund, dvs. hinduer og muslimer, dermed politisk indflydelse i kolonitidens Indien - de var blevet organer for politiske mål. ${ }^{2}$

I uafhængighedsbevægelsen kæmpede et flertal i kongressen stadig for en sekulariseret version af den indiske nation. Men “the Muslim League” førte en kampagne for en separat muslimsk stat i Sydasien. Dette krav var baseret på “the Two-Nations-Theory”, som indebærer, at nationer er baseret på religiøst tilhørsforhold, og at der som følge heraf er to nationer på subkontinentet, en hinduistisk og en muslimsk nation. Skønt der ikke var enighed blandt alle indiske muslimer om denne nationalitetsversion baseret på religion, blev den endeligt stadfæstet og legitimeret af briterne gennem deres billigelse af subkontinentets deling. Med denne beslutning blev den britiske opbygning af det indiske samfund som ‘decentralt’ og som i sit væsen defineret ved en antagonisme mellem hinduer og muslimer, endelig ført ud i livet.

Indien blev grundlagt som en sekulær stat uden hensyn til dets indbyggeres religiøse tilhørsforhold. Den officielle version af indisk nationalitet blev udtrykt gennem en 'unitin-diversity’-diskurs. Bag denne diskurs lå forestillingen om, at det indiske samfund byggede på religiøs pluralisme. Gennem hindunationalistiske organisationer som RSS (Rashtriya Swayam Sevak Sangh, som blev grundlagt allerede før uafhængigheden, jf. Anderson \& Damle 1987 og Jaffrelot 1996), var der stadig en aktiv antisekularistisk og antipluralistisk version af den indiske nationalopfattelse, skønt den i løbet af de næste få årtier stort set ikke slog igennem politisk. Ideologien bag den politiske hinduisme eller hindutva appellerede kun til få. Det hindunationalistiske parti Bharatiya Janata Party (BJP), efterfølgeren af Jan Sangh, som havde siddet i Janata Party-regeringen i 1977, begyndte at føre en kampagne med et ultra-hinduistisk sigte i midten af 1980'erne. Det gjorde Jan Sangh efter at have stillet op til tidligere valg uden nævneværdig succes. Den formentlig tavse hindu-majoritet blev i denne forbindelse fremstillet som værende underkuet af magtfulde minoriteter såsom muslimer og 'urørlige'. At dømme efter disse kampagner var Indien stadig ikke frit og ikke styret af dem, som landet retmæssigt tilhørte.

\footnotetext{
${ }^{1}$ Frykenberg 1987. Searle-Chatterjee (1994a og b) skriver, at selv i dag bliver 'de urørlige’ undertiden ikke opfattet som rigtige hinduer.

${ }^{2}$ Dette betyder imidlertid ikke, at religiøst motiveret politik i alle tilfælde delte hinduer og muslimer. Under Khilafat-bevægelsen $\mathrm{fx}$, støttede mange hinduer de indiske muslimers krav om videreførelse af kalifatet (Minault 1982).
} 
De hindunationalistiske organisationer brugte den hinduistiske pilgrimspraksis (yatra) som massemobiliserende middel i hindutvas tjeneste (se van der Veer 1994, 124ff; Assayag 1998, 135). Det centrale punkt i BJPs kampagner blev spørgsmålet om Babri Masjid-moskéen ved Ayodhya. Ifølge den hindunationalistiske version af historien havde mogulkejseren Babar i det 16. århundrede beordret, at et tempel, der markerede fødestedet for hinduguden Rama i denne by, skulle ødelægges, og at der i stedet skulle bygges en moské på dets plads. Kampen om dette sted, som den kommer til udtryk i dag, er ikke ny, men har fortilfælde allerede i det 19. århundrede. ${ }^{3}$ Både BJP og dets søsterorganisationer RSS og VHP (Vishwa Hindu Parishad) gjorde stedet til et magtfuldt symbol på fortsat 'fremmedherredømme' i Indien. Ifølge deres retorik var ingen af hinduernes helligste steder fri for 'fremmed' (dvs. muslimsk) indtrængen, og hinduerne, dvs. de 'rigtige' indere, var ufrie i deres eget land. I slutningen af 1992 resulterede en demonstration ved Ayodhya, som var organiseret af BJP og VHP, i, at Babri Masjid-moskéen blev ødelagt. De hindunationalistiske kampagner havde næsten altid være ledsaget af kollektiv vold. Denne vold kulminerede i de uroligheder, der fulgte efter ødelæggelsen af moskéen, som i Bombay alene forårsagede mere end tusinde døde, hvoraf de fleste var muslimer (van der Veer 1994, 7).

I eksemplet med hindunationalismen ser man samme anvendelse af religiøs symbolik, som Duijzings peger på med hensyn til Balkan. Religiøse symboler anvendes til at markere nationens grænser og til mobiliseringsformål. Hinduer i Indien deltager i pilgrimsfærd (yatras), hvorved de ved at drage igennem Indien markerer landet som område for den hinduistiske nation. De tilbeder således den guddommeliggjorte nation og følger de ledere, som spiller på forestillingen om, at de er gudernes manifestationer (van der Veer 1994). Kun hinduer er medlemmer af den indiske nation. På den måde redefineres den indiske stat, den homogeniseres, og religiøs pluralitet udelukkes. Men det er ikke kun opfattelsen af nationen, der forandres, ved den religiøse applikation. Også hinduismen redefineres og homogeniseres. Fx introduceres en ny gudeikonografi (Kapur 1993), ligesom myter og trossætninger standardiseres. Dette effektueres gennem en stærkt hindunationalistisk ideologi, ligesom de hinduistiske eper fremstilles som essentielle dele af Indiens nationale arv.

Sudipta Kaviray henviser til, at det var koloniadministrationens folketællinger, der skabte, hvad Kaviray kalder en rekonstituering af identiteternes ontologi i Indien (jf. 1997, 329). Faktisk kan hele processen fra kolonistyrets opstilling af kategorier til dannelsen af hindunationalisme fortolkes som en proces, hvor identiteter bliver konkretiseret, men samtidig også gjort mere abstrakte. Uigennemskuelige samfundsgrupper blev gennem folketællinger forvandlet til klart specificerede grupper (Kaviray 1996, 20f). Dvs., at kategorier af mennesker, hvad enten de blev defineret ved kaste, regionalt eller religiøst tilhørsforhold, blev rekonstitueret som forestillede ("imagined") homogene enheder. I denne nyskabte forestilling om et identitetslandskab i Indien var der ikke plads til ambivalente relationer, der gik på tværs af de markerede grænser, og de fleste

\footnotetext{
${ }^{3}$ På den tid var problemet dog lige omvendt, idet muslimer klagede over, at der blev bygget et tempel på et sted, hvor moskéen tidligere havde stået (Panikkar 1993, 30f).
} 
opløstes. Denne nyskabte forestilling om identiteter er drevet til ekstremer af den hindunationalistiske ideologi, fordi den pluralisme, som har været så kendetegnende for nationen $i$ andre sammenhænge, nu blev udelukket ved etableringen af en kongruens mellem det religiøse og det nationale. Ved denne 'identitetsdublering' er de former for fællesskaber, der bygger på fælles tilknytning til en region eller en landsby, ofte helt væk. I dette perspektiv bliver en muslim fra samme landsby som en hindu simpelthen 'den anden', som man ikke har noget positivt forhold til, og som i tilfælde af tilspidsede situationer og nationalistiske kampagner kan blive udsat for voldelige overfald. Denne applicering af en national identitet på en religiøs fører således til polarisering og depluralisering af identiteter. Standardisering - som ifølge Ernest Gellner (1983) er et generelt træk ved nationalisme - fremmes, når religiøs pluralisme udelukkes, fordi det nationale samfund forestilles at være religiøst homogent.

\section{Nationalisme versus religion}

Religiøs nationalisme er ikke et nødvendigt udslag af relationer mellem religiøse og nationale identiteter. Ethvert forhold mellem begge slags forskelle er betinget af historiske omstændigheder. I dette afsnit vil jeg præsentere et eksempel på, hvordan religiøs og national identitet ikke kongruerer, men hvordan en nationalistisk ideologi bestræber sig på at udviske eller i det mindste moderere religiøse forskelle. Jeg refererer til konflikten mellem shi'a- og sunnimuslimer i det nordlige Pakistan, især områdets hovedstad Gilgit, og hvordan denne konflikt står i forbindelse til en lokal nationalistbevægelse.

I tiden fra begyndelsen af 1970'erne til midten af 1990'erne var der en stigende forekomst af voldelige sammenstød mellem shi'a- og sunnimuslimer i Gilgit, som i nogle år resulterede i op til tredive dødsfald. Byens befolkning er næsten ligeligt delt mellem de to retninger. Desuden findes der et mindretal af ismaelitter, som ikke blev indblandet i konflikten. Fjendskabet mellem shi’a- og sunnimuslimer er næsten lige så gammelt som islam. Men i Gilgit siges det, at denne forskel ikke har haft nogen væsentlig betydning før begyndelsen af 1970’erne. Der har været eksempler på konflikter før 1970, men det er almindeligt accepteret, at det først var i 1970'erne, at forskellen mellem de to retninger fik en fremtrædende karakter, hvilket kom til udtryk ved en opdeling af Gilgits indbyggere. Det er ikke helt klart, hvad der affødte konflikten, men det lader til, at nogle ulam_s (skriftlærde) inden for begge retninger på dette tidspunkt begyndte at stille spørgsmål ved, om medlemmerne af den anden gruppe var rigtige muslimer eller ej. Især blev shi' amuslimernes særlige rituelle praksis et omstridt emne. Særligt var sørgeprocessionen på ash_ra (den tiende dag i muharram), hvor shiitterne sørger over Imam Husseins og hans venners martyrium i slaget ved Kerbela, omdiskuteret. Striden tvang gradvis Gilgits indbyggere til at identificere sig selv som enten sunni- eller shi'amuslimer. Det er flere gange blevet udtalt, at man før den tid ikke vidste nøjagtigt, hvilken retning den anden tilhørte, og shi'a- og sunnimuslimer bad ofte sammen i samme moské. Det, der efter sigende kun havde været en nominel forskel, fik nu pludselig betydning i indbyggernes sociale liv. Siden begyndelsen af 1970'erne er der fx ikke indgået ægteskab mellem shi’a- og sunnimuslimer, hvilket står i modsætning til tidlige- 
re, hvor blandede ægteskaber ikke var ualmindelige. I 1980'erne blev forskellen tematiseret i den politiske debat, og ved lokalvalgene blev valgtalernes appel til det at høre til én af de to trosretninger den vigtigste strategi for at vinde stemmer. I 1988 kulminerede den spændte situation i en massakre, da sunni-krigere fra Kohistan i de sunnidominerede områder i det nordlige Pakistan angreb shi’ittiske landsbyer i omegnen af Gilgit, hvor de ødelagde huse, marker og træer og dræbte mange mennesker (Sökefeld 1997b, 205ff). Herefter blev voldelige sammenstød nærmest vanlige begivenheder ind til midten af 1990'erne.

Der skete en effektiv polarisering af samfundet i Gilgit som følge af den skarpe adskillelse mellem shi'a- og sunnimuslimer. Sunnimuslimske familier, der boede i de områder, hvor shi'amuslimer udgjorde en majoritet, flyttede til sunnidominerede områder. Der var en tydelig nedgang i det økonomiske samarbejde på tværs af de religiøse grænser, ligesom dagligt samvær mellem shi’a- og sunnimuslimer stort set ophørte. Modsætningen mellem shi'a- og sunnimuslimer blev den præmis, hvor ud fra opfattelsen af det sociale rum blev dannet. Religiøs identitet blev i mange sammenhænge den vigtigste identitet. Dette betyder dog ikke, at mangfoldighed og intersektionalitet blev fuldstændigt elimineret. Det kunne i stedet iagttages, at indbyggerne i visse sammenhænge udtrykkeligt forsøgte at fremhæve andre identiteter på bekostning af de religiøse forskelle.

Som følge af den aktuelle konflikt i Kashmir anses det nordlige Pakistan, som først var under herredømme af Kashmirs maharaja og senere under britisk, for at være såkaldt 'omstridt territorium' og er endnu ikke formelt set en integreret del af Pakistan. Dette forhold resulterer i, at befolkningen i det nordlige Pakistan ikke har lov til at stemme til den pakistanske nationalforsamling. Siden sidste halvdel af 1980'erne er der i Gilgit dannet en stærk opposition mod den særlige politiske status, som det nordlige Pakistan har været underlagt. Allerede tidligere havde Gilgit være skueplads for protester mod dette forhold. Af størst betydning var det store oprør mod den pakistanske administration i 1971 (Sökefeld 1997b, 282ff). I den lokalpolitiske debat er politisk status ofte forbundet med den religiøst motiverede konflikt, fordi denne først opstod efter dette oprør. Det antages derfor, at administrationen fik den religiøst motiverede konflikt til at blusse op som en del-og-hersk-strategi rettet mod den politiske protest.

I slutningen af 1980'erne udviklede den nye opposition sig gradvist på nationalistiske præmisser. Politiske grupper i det nordlige Pakistan gjorde krav på en selvstændig nation, der var skabt af historien, kulturen og de unikke sproglige og geografiske forhold (Sökefeld 1997b, 296ff; Sökefeld 1999a). Nationalisme viste sig at være en tveægget strategi, idet den ikke blot fremhævede forskellen mellem det nordlige Pakistan og resten af Pakistan ved at fornægte Pakistans ret til at bestemme over områdets skæbne, men samtidig bekræftede den 'naturlige' enhed blandt befolkningen i det nordlige Pakistan som én nation. At fremme denne enhed, som havde været sat på spil af det officielle Pakistans nedbrydende strategi, fik afgørende betydning. Den største trussel mod den nationale enhed var naturligvis adskillelsen af de muslimske retninger.

Den påståede del-og-hersk-strategi blev mødt af en ny repræsentationspolitik, som fremstillede indbyggerne i det nordlige Pakistan som én nation, der fundamentalt set var 
forenet og naturligt forskellig fra Pakistans øvrige befolkning. Forsøget på at erstatte forskellen i religion med en forskel i nation fandt sted i et indviklet væv af overlappende diskurser. Der var fx ikke nogen klar afgrænsning af den 'politiske' og 'religiøse' diskurs i Gilgit. Især shi' ittiske funktionærer forbandt de to med hinanden ikke blot med det argument, at opsplitningen af de muslimske grupper kunne forstås som en nedbrydende regeringsstrategi imod et politisk engagement og imod forandring i området, men også med argumentet om, at den politiske diskrimination i det nordlige Pakistan hovedsageligt var en diskrimination af shi'itter. Sagen er blevet yderligere kompliceret af den ustabile politiske situation i Pakistan med hyppigt skiftende regeringer inden for det sidste årti. Ganske vist blev den religiøse diskurs og den religiøse antagonisme ikke fuldstændig erstattet af en nationalistisk diskurs, der primært drejede sig om opnåelsen af en national enhed i det nordlige Pakistan. Men Pakistan stod faktisk i løbet af 1990'erne meget tydeligere end nogensinde før frem som 'den anden' i forhold til det nordlige Pakistan. Og der har ikke været voldelige sammenstød mellem shi’a- og sunnimuslimer siden sidste halvdel af 1990'erne.

\section{Identitetspolitik}

I de eksempler, der her er præsenteret, er komplekse identitetsprocesser på spil. Det viser, at identiteter ikke skal forstås som singulære kategorier, men som rammer for fortolkning og interaktion skabt under bestemte historiske vilkår. Identiteter rummer her et bestemt verdenssyn og bestemte former for handlingsmønstre. Hvis vi vender tilbage til eksemplet med identitetskortet, bliver det klart, at spørgsmål vedrørende identitet ikke besvares udtømmende ved $\mathrm{fx}$ at spørge, om en person er hindu eller ej. Det er derimod vigtigere, men også mere kompliceret, at spørge om, hvad det betyder at være hindu og hvilke specifikke handlingsmønstre, der er (eller bør være) knyttet til en sådan identifikation. Samfundsmæssige identitetsprocesser berører som noget helt centralt disse problemstillinger. Det er klart, at identiteter ofte er forbundet med bestemte verdenssyn, når det drejer sig om religiøse identiteter, idet de implicerer bestemte forestillinger om kosmologi, værdier, etik osv. Men det samme gælder for nationaliteter, der er forbundet med specifikke historiske anskuelser og konstruktioner. Det er væsentligt at huske, at sådanne anskuelser og konstruktioner faktisk ikke, som det forventes, altid deles af alle i en gruppe. Alle, der identificerer sig som hinduer, er naturligvis ikke enige om, hvad det betyder at være hindu, og ikke alle indbyggerne i det nordlige Pakistan er enige om, hvad deres nationalitet indebærer. Denne uenighed udgør den fundamentale årsag til den identitetspolitik, som forsøger at overbevise de formodede medlemmer af en gruppe om, at bestemte anskuelser og konstruktioner er de rigtige. Dvs., at identitetspolitik ikke kun arbejder mod at udelukke bestemte 'andre' grupper, men, hvilket er endnu vigtigere, den retter sig mod sin egen gruppe med den hensigt at forme bestemte holdninger hos den.

At tale om identitetspolitik er at tale om 'agency', hvor der er nogle aktører, der fører én bestemt form for politik, og andre, som denne politik er rettet mod for at få dem til at handle på bestemte måder. En sådan type 'agency’ arbejder normalt gennem en 
institution eller organisation, hvor visse ideer og strategier formuleres, mangfoldiggøres og udføres, som om der ligger fuldstændig enighed bag og uden at eventuelle interne meningsforskelle kommer til udtryk.

I ordet 'politik' er det allerede underforstået, at sådanne identitetsprocesser er tæt forbundne med magtprocesser. Magt opererer på mange måder i og gennem identitetspolitik. For det første er identitetspolitik naturligvis i de fleste tilfælde selv en magtstrategi, hvorigennem visse mål søges opnået. I tilfældet med det nordlige Pakistan forestillede man sig en nation, fordi alle tidligere forsøg på at opnå politisk indflydelse til lokalbefolkningen var faldet til jorden. Nationalistisk diskurs skabte i dette tilfælde ikke kun en ny fællesskabsfølelse, der modsatte sig pakistansk dominans, men gav også en legitimering af dens krav, fordi den nu kom til udtryk under dække af at repræsentere hele kollektivet. Magt opererer desuden inden for det formodede kollektiv, fordi de forskellige opfattelser af nationen konkurrerer indbyrdes, og fordi de individuelle aktører kæmper mod bevægelser og organisationer om visse magtpositioner. Der var således ikke kun ét nationalistparti i Gilgit, men der var flere aktører med forskellige navne og grader af inklusivitet, der på samme tid havde deres specifikke forestilling om nationen (Sökefeld 1997b, 296ff).

\section{Forskel, mangfoldighed og intersektionalitet}

Identitetspolitik forholder sig til alle de tre aspekter, som jeg refererede til i begyndelsen af artiklen. Identitetspolitik forudsætter naturligvis pluralisme, for kun i en kontekst med forskellige identiteter og forskellige versioner af identitet bliver definitionen og afgrænsningen af identiteter et omstridt spørgsmål. Gennem identitetspolitikken peges der på eller konstrueres specielle former for forskelle. Men vigtigst er dog forholdet mellem identitetspolitik og intersektionalitet. En identitetspolitik må være meget følsom over for identiteters intersektionalitet. For at plædere for en bestemt identitetsversion skal den tage højde for forholdet til andre identiteter. I tilfældet med hindunationalisme var det fx nødvendigt at ekskludere muslimer fra nationsbegrebet, mens andre religiøse identiteter - især sikher - blev inkluderet i en rekonceptualisering af hinduisme. I det nordlige Pakistan kunne ideen om en fælles nation forskellig fra Pakistan kun muliggøres, hvis indbyrdes markante forskelle - og her er der ikke kun tale om religiøse skel, men også om sproglige og regionale - blev trængt i baggrunden som sekundære. Identitetspolitik har i denne forbindelse til formål at reducere eller endog udelukke intersektionalitet. Den bestræber sig på at homogenisere en bestemt identitet ved at nedtone alle de former for forskelle, der henviser til det modsatte (jf. van Beek 2000). Men ved at nedtone og benægte intersektionalitet sættes der skel mellem de respektive former for forskelspolitik og andre forskelssættere.

I de to hovedeksempler, der er blevet diskuteret, gik intersektionalitet, nationalitet og religion i hver sin retning. Mens opfattelsen af nationen i det hindunationalistiske eksempel bekræftede religion og religiøs forskel, så viste det modsatte sig i eksemplet 
fra det nordlige Pakistan. I begge tilfælde kom der nye forslag til, hvordan nationen skulle opfattes i forhold til tidligere. I Pakistan var den dominerende opfattelse af nationen grundlagt på religiøs forskel, fordi Pakistan blev skabt som nation for Sydasiens muslimer. Pakistans historie siden uafhængigheden kan forstås som en kamp for at komme overens med denne kategorisering. På den ene side krævede islamiske grupper, at muslimernes stat i Sydasien skulle omdannes til en islamisk stat, og satte en islamiseringsproces i gang, som fra og med Zia ul Haqs diktatur blev omsiggribende. Fordi 'islamisering' kun blev udtænkt i overensstemmelse med den dominerende sunniversion af islam, resulterede islamiseringspolitikken i en større kløft mellem de to store muslimske grupper, hvilket affødte voldelige konflikter i mange dele af landet. På den anden side opstod der regionale og separatistiske bevægelser, hovedsageligt i Baluchistan og Sindh, hvilket markerede, at den tilsyneladende fælles religiøse identitet som muslim ikke var tilstrækkeligt fundament for dannelsen af en uomtvistelig nationalfølelse. Nationsbegrebet i det nordlige Pakistan vendte op og ned på forholdet mellem nationalt og religiøst tilhørsforhold. Det religiøse tilhørsforhold var ikke fundamentet for nationen, men i stedet en meget alvorlig trussel mod dens enhed.

I modsætning hertil brugte man i Indien ikke religion som kriterium for eksklusion i den dominerende nationsform. Denne opfattelse af nationen var en transformation og udvidelse af det nationsbegreb, der var opstået i Europa, da den i det mindste i den officielle diskurs ikke byggede på ideen om en fælles national kultur. Hindunationalisme tilbagekaldte denne udvidelse af nationsbegrebet ved at ty til religion som kriterium for både inklusion og eksklusion. Kun de religio-kulturelle traditioner, som var opstået inden for grænserne af subkontinentet, blev anset for at være indiske (og sådan set også hinduistiske). Derfor blev både muslimer og kristne ekskluderet, da de blev opfattet som efterkommere af fremmede, ikke-nationale erobrere og kolonisatorer. Nationen er homogeniseret ved både at ekskludere en betydelig sektion af befolkningen, som tidligere havde været inkluderet, og ved at nedtone de resterende forskelle.

\section{Essentialisme taget op til fornyet overvejelse}

I denne artikel har jeg diskuteret to eksempler, hvor der sættes skel mellem religiøs identitet og national identitet. Jeg har argumenteret for, at identitet ikke skal ses som en særlig kategori, men snarere som det, der konstituerer et komplekst, interrelateret system af forskelle, hvor en bestemt type forskel ikke kan analyseres isoleret fra de andre. Religion er derfor blot én type forskel i dette system af inklusion og eksklusion. Denne tilgang er meget bekvem og overbevisende, så længe vi ser på situationen udefra. Den tillader os at analysere, hvordan særlige forskelle forestilles og skaber forestillede samfund og hvordan sådanne forestillinger mobiliserer mennesker og tjener som strategier i de magtspil, der finder sted blandt dem, der trækker i trådene. For en udenforstående analytiker synes dette at være et spørgsmål om falsk bevidsthed, og der argumenteres til tider for, at de skabte 'etniske', 'religiøse' eller andre slags identitetskonflikter ville kunne løses, hvis blot det røgslør, der ligger omkring identitet, blev fjernet, så man kunne se, hvad det i virkeligheden drejer sig om. 
Jeg har dog nogle forbehold over for denne tilgang. Jeg ønsker naturligvis ikke at argumentere for en slags identitetsmystik eller en genoplivning af 'primordialismen', som tager identitetskonstruktioner for pålydende. Men jeg vil påpege, at det stadig er vigtigt at skelne mellem de forskellige perspektiver, selvom dette er omstridt inden for antropologien. Ifølge lingvisten Kenneth Pikes begreber, skelner antropologer mellem etic og emic. Man går ved denne skelnen ud fra, at verdensanskuelser dannes ud fra bestemte kulturelle præmisser. Kort fortalt er etic-perspektivet den udenforstående analytikers opfattelse, som ikke er præget af den kultur, der undersøges. Hans eller hendes perspektiv er komparativt og derfor mere eller mindre objektiverende. Han eller hun kan afdække kulturelle præmisser. Vedkommende bedømmer ikke ud fra en kulturel partikularisme, men ud fra en universel rationalitet. Emic-perspektivet derimod er den opfattelse, der tager udgangspunkt i kulturen indefra. Perspektivet er præget af, at man er involveret og ikke distanceret.

Siden antropologien blev en moderne, empirisk videnskab, har den set det som et af sit vigtigste mål også at repræsentere dette emic-perspektiv, eller som Malinowski kalder det, "the native point of view". Der har naturligvis udviklet sig en heftig debat omkring disse begreber. Det er fx omstridt, hvorvidt et tilsyneladende etic-perspektiv virkelig er etic og ikke blot endnu et emic-perspektiv, eller hvorvidt antropologi ikke blot koloniserer andres livsverdener ved at spærre dem inde i emic-kulturelle verdener (jf. debatten i Headland m.fl. 1990). Jeg mener, at den epistemologiske forskel, der ligger i denne distinktion, er endog meget tvivlsom (Sökefeld 2001).

Denne skelnen mellem emic og epic peger imidlertid på noget meget vigtigt, nemlig at der er andre synspunkter end det distancerede, bevidst komparative og analytiske. I den konstruktivistiske identitetsdiskurs bliver emic-perspektivet, eller som jeg foretrækker at sige, det perspektiv, der bygger på de involveredes og engageredes erfaring, alt for hurtigt fejet til side. Konstruktivismen løber den risiko at kategorisere identitetskonstruktioner som simpelthen uvirkelige. Men Benedict Anderson har over for Gellner insisteret på, at fællesskaber ikke er uvirkelige, blot fordi de er forestillede. Tværtimod er forestillede fællesskaber virkelige, fordi de forstås som virkelige i en mere skærpet betydning. De er omgærdet af en virkelighed, der strækker sig langt ud over den nuværende - konstruerede - aktualitet. Dvs., at de kan være virkelige, selvom de endnu ikke er realiserede - deres virkelighed kræver deres virkeliggørelse. "The premise is faulty, but if phenomena are real in their effects, they are real; this is the power of primordial arguments”, skriver Edwin Wilmsen (1996, 2).

Hvis det at være involveret $i$ en religiøs og også en national identitet beskrives som blot en magtstrategi, der trækker på visse konstruktioner, som letter mobiliseringen, opfanges ikke det perspektiv og den selvopfattelse, der kommer til udtryk hos de fleste involverede. For en ivrig tilhænger af VHP er det sikkert ikke en konstruktion og en strategi, men simpelthen sandheden, at hinduismen er Indiens religion, og at hinduer er blevet undertrykt og udnyttet af fremmede i deres eget land. Tilsvarende mener en tilhænger af en nationalistisk ideologi i det nordlige Pakistan ikke selv at have opfundet en ny version af historien, men at have afdækket den virkelige historie, sandheden, som viser, at den nuværende tilstand er illegitim og derfor bør forandres. 
Den motivation, der driver mange forkæmpere for religiøs og national identitet er ikke blot en opfattelse af, at deres egne interesser er blevet krænket, men også en stræben efter sandheden - dvs. efter en eller anden værdi, der menes at strække sig langt ud over egen interesse. Efter Foucault er det vanskeligt ikke at opfatte en sådan 'sandhed' simpelthen som en projektion af magt, og som en retorik, der - igen - kun lægger et røgslør over 'viljen til magt'. Men jeg er af den opfattelse, at vigtige aspekter af de involveredes erfaring og motivation går tabt - og derfor vigtige aspekter af identitetsprocessernes virkelighed - hvis vi ikke her standser op et øjeblik.

Repræsentanter for den seneste identitetsforskning har fremhævet dette. I sin undersøgelse af sikhmilitarisme diskuterer Cynthia Mahmood (1996) også sikhernes skarpe reaktion på et historisk værk af en sikhforsker, Harjot Oberoi, som beskriver sikhidentitet som en konstruktion og en reifikation, skabt under særlige historiske omstændigheder (Oberoi 1994). Oberoi dekonstruerer på denne måde sikhidentiteten. Ifølge Mahmood skal denne dekonstruktivistiske position inden for antropologi forstås som en reaktion mod den tidligere praksis inden for disciplinen, hvor kulturer, identiteter osv. konstrueres og reificeres. Den er resultatet af “a belated recognition of the discipline's partnership with the colonial enterprise which used imposed identities to control and ultimately exclude others” (Mahmood 1996, 243). Denne dekonstruktivistiske position fremstår således som en tilgang, der tilsyneladende modsætter sig den kompromissøgende, disciplinære deltagelse i identitetspolitik. Richard Handler (1985) kræver eksplicitte, 'dekonstruktive' analyser af identiteter for at undslippe problemerne med nationalisterne.

Men en anti-essentialistisk dekonstruktion er ikke en upolitisk tilgang, siger Mahmood, der netop mener at kunne iagttage en ny “congruence of postmodern ethnograpnhy with the kind of power that asserts itself not by imposing but by denying group identities ...” (1996, 244). Talal Asad tilføjer:

\footnotetext{
It is a notorious tactic of political power to deny a distinct unity to populations it seeks to govern, to treat them as contingent and indeterminate ... It is precisely the viewpoint of interventionist power that insists on the permeability of social groups, and unboundedness of cultural unities, and the instability of individual selves (1990).
}

Hverken den reificerende forfægtelse af identiteter eller deres dekonstruerende benægtelse undgår politiske forviklinger. Den anti-essentialistiske, dekonstruktive position risikerer at benægte og ødelægge denne aktivitet. Forskning, der beskæftiger sig med identitet alene, kommer uundgåeligt ind i den identitetspolitiske problematik, når identitetsprocesser og -diskurser beskrives og repræsenteres i videnskabelige værker. Stadig oftere må historikere, antropologer og andre forfattere stå skoleret over for de individer, de skriver om. Der er ikke noget sted, hvor man kan diskutere rent videnskabeligt, uafhængigt af politiske anliggender. Mahmood forsøger at skelne de identiteter, der yder modstand, fra de identiteter, som dominerende magtudøvere har påtvunget andre. Hun foreslår, som tingene ser ud nu, at “the ‘destruction’ of group identities is not a progressive but a regressive act, and it is the exploration of denied group identities that is the 
most politically challenging avenue of contemporary research” (1996, 245). Således er det nogle gange svært helt nøjagtigt at skelne mellem modstandsyderes og de dominerende magtudøveres identitetskonstruktioner. Når én gruppes identitet fornægtes, er det i mange tilfælde blot udtryk for, at en anden gruppes identitet bekræftes, som det er tilfældet med de indiske muslimer, der afskrives ‘indiskhed’ af hindunationalister.

\section{Konklusion}

At begrebsliggøre identitet ved, som foreslået i denne artikel, både at se på pluralisme, forskel og intersektionalitet, som foreslået i denne artikel, er i høj grad en tilsidesættelse af essentialismen. Men det sætter fokus på ‘agency’ forstået som aktørers refleksionsevne på baggrund af tværgående identifikationer (Sökefeld 1999b). Aktører med denne refleksionsevne kan både skabe forestillinger og inddrage essentialiserede identiteter, hvilket for et øjeblik tilsidesætter samspillet med andre identifikationer. Vi bør begrebsliggøre ‘identitet’ på en måde, som både kan rumme aktørernes essentialisering og analysens dekonstruktion (jf. Sökefeld 2001). Uanset den betydning, som vore fremstillinger og analyser af identitetsprocesser og -diskurser tillægges i en verden, hvor identiteter tjener som legitimation for diskrimination og vold, finder jeg det absolut nødvendigt at være opmærksom på de mulige følger, som vore repræsentationer har, og derfor arbejde med en høj grad af reflekterethed.

\section{Litteratur}

ANDERSON, WALTER K. \& SHRIDAR D. DAMLE

1987 The Brotherhood in Saffron: The Rashtriya Swayamsevak Sangh and Hindu Revivalism, Boulder.

ASAD, TALAL

1990 "Ethnography, Literature and Politics”, Cultural Anthropology 5, 239-69.

ASSAYAG, JACKIE

1998 "Ritual Action or Political Reaction? The Invention of Hindu Nationalist Processions in India During the 1980s”, South Asia Research 18, 125-48.

DUIJZINGS, GER

2000 Religion and the Politics of Identity in Kosovo, London.

ERIKSON, ERIK H.

1980 Identity and the Life-Cycle, New York.

FREITAG, SANDRIA B.

1989 Collective Action and Community: Public Arenas and the Emergence of Communalism in North India, Berkeley.

FRYKENBERG, ROBERT E.

1987 “The Concept of 'Majority’ as a Devellish Force in the Politics of Modern India”, Journal of Commonwealth History and Comparative Politics 25, 267-74.

GELLNER, ERNEST

1983 Nations and Nationalism, Ithaca.

HANDLER, RICHARD

1985 "On Dialogue and Destructive Analysis. Problems in Narrating Nationalism and Ethnicity”, Journal of Anthropological Research 41, 171-82. 
Headland, T., Kenneth L. Pike \& Marvin Harris, eds.

1990 Emics and Etics: The Insider/Outsider Debate, Newbury Park.

JAFFRELOT, CHRISTOPHE

1996 The Hindu Nationalist Movement in India, New York.

KAPUR, ANURADHA

1993 “ Deity to Crusader: The Changing Iconography of Ram”, Gynanendra Pandey, ed., Hindus and Others. The Question of Identity in India Today, Delhi, 74-109.

KAVIRAJ, SUDIPTA

1996 "The Imaginary Institution of India”, Partha Chatterjee og Gynanendra Pandey, eds., Subaltern Studies VII, Delhi 1-39.

KAVIRAJ, SUDIPTA

1997 “Religion and Identity in India”, Ethnic and Racial Studies 20, 325-44.

MAHMOOD, CYNTHIA KEPPLEY

1996 Fighting for Faith and Nation. Dialogues with Sikh Militants, Philadelphia.

MARTY, MARTIN E.

1997 "Introduction: The Role of Religion in Cultural Foundations of Ethnonationalism”, Martin E. Marty and R. Scott Appleby, eds., Religion, Ethnicity and Self-Identity, Hannover, $1-18$.

MinAULT, GAIL

1982 The Khilafat Movement. Religious Symbolism and Political Mobilization, New York.

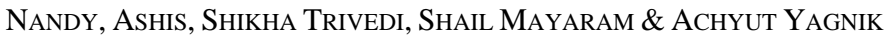

1997 Creating a Nationality. The Ramjanmabhumi Movement and the Fear of the Self, Delhi.

OBERNDÖRFER, DIETER

2000 “Deutschland ein Mythos? Von der nationalen zur postnationalen Republik”, Yves Bizeul, ed., Politische Mythen und Rituale in Detuschland, Frankreich und Polen, Berlin, 161-96.

OBEROI, HARJOT

1994 The Construction of Religious Boundaries. Culture, Identity, and Diversity in Sikh Tradition, Berkeley.

PANDEY, GYNANENDRA

1993 “Which of Us Are Hindus?”, Gynanendra Pandey, ed., Hindus and Others. The Question of Identity in India Today, Delhi, 238-72.

1996 The Construction of Communalism in Colonial North India, Delhi.

PANIKKAR, K.N.

1993 “A Historical Overview”, Sarvepalli Gopal, ed., Anatomy of a Confrontation. Ayodhya and the Rise of Communal Politics in India, London, 22-37.

SCHUlZE, HAGEN

1999 Staat und Nation in der europäischen Geschichte, München.

SEARLE-ChATTERJEe, MARY

1994a “Urban 'Untouchables’ and Hindu Nationalism”, Immigrants \& Minorities 13, 12-25.

1994 b “Caste, Religion and other Identities”, Mary Searle-Chatterjee \& Ursula Sharma, eds., Contextualizing Caste. Post-Dumontian Approaches, Oxford, 147-68.

SÖKEFELD, MARTIN

1997a “On the Concept 'Ethnic Group’”, Irmraud Stellrecht, ed., Karakorum - Hindukush Himalaya. Dynamics of Change, Vol. 2, Köln, 383-404.

1997b Ein Labyrinth aus Identitäten in Nordpakistan: Zwischen Landbesitz, Religion und Kashmirkonflikt, Köln. 
1997c “Jang azadi: Perspectives on a Major Theme in Northern Areas' History”, Irmtraud Stellrecht, ed., The Past in the Present. Horizons of Remembering in the Pakistan Himalaya, Köln, 61-82.

1999a "Balawaristan and Other ImagiNations: A Nationalist Discourse in the Northern Areas of Pakistan”, Martijn van Beek, Kristoffer Brix Bertelsen \& Poul Pedersen, eds., Ladakh: Culture, History, and Development between Himalaya and Karakoram, Århus, 350-68.

1999b "Debating Self, Identity, and Culture in Anthropology", Current Anthropology 40, 41747.

2001 "Reconsidering Identity”, Anthropos 96, 527-44.

BEEK, MARTIJN VAN

2000 “Dissimulations: Representing Ladakhi Identity”, Henk Driessen \& Ton Otto, eds., Perplexities of Identification. Anthropological Studies in Cultural Differentiation and the Use of Resources, Århus, 164-88.

VEer, PETER VAN DER

1994 Religious Nationalism. Hindus and Muslims in India, Berkeley.

WILMSEN, EDWIN N.

1996 "Introduction: The Premise of Power in Ethnic Politics", Edwin N. Wilmsen \& Patrick MacAllister, eds., The Politics of Difference. Ethnic Premises in a World of Power, Chicago, 1-23.

\title{
Summary
}

The conceptualization of identity proposed in this article is in terms of plurality, difference and intersectionality, which certainly disfavours essentialism. However, it highlights agency as the ability to act reflexively within settings of crosscutting identifications. This agency includes the ability to imagine and engage essentialised identities, momentarily dissimulating intersecting identifications. This article will stress that we have to conceptualize 'identity' in a way that is able to accomodate both the essentialisations of actors and the deconstruction of analysis.

\author{
Martin Sökefeld \\ Lektor \\ Institut for socialantropologi \\ Hamborg Universitet
}

